\title{
OcCURRENCE OF DEPRESSIVE DISORDERS AMONG STUDENTS of the Faculty of Health Sciences of the Jagiellonian University Medical College
}

Katarzyna Anna Czyżowicz ${ }^{1 \mathrm{~A}, \mathrm{C}, \mathrm{D}, \mathrm{E}, \mathrm{F}}$, Joanna Sitarz ${ }^{2 \mathrm{~A}, \mathrm{~B}, \mathrm{C}, \mathrm{E}, \mathrm{F}}$, Katarzyna Wojtas $^{1 \mathrm{D}, \mathrm{E}, \mathrm{F}}$

'Department of Clinical Nursing, Institute of Nursing and Midwifery, Faculty of Health Sciences, Jagiellonian University Medical College, Krakow, Poland

¿Laboratory of Medical Analyzes, ALAB Laboratories Sp. z o.o., Poland

Authors' contribution:

A. Study design/planning $\bullet$ B. Data collection/entry $\bullet$ C. Data analysis/statistics $\bullet$ D. Data interpretation $\bullet$ E. Preparation of manuscript $\bullet$ F. Literature analysis/search $\bullet G$. Funds collection

\author{
Address for correspondence: \\ Katarzyna Anna Czyżowicz \\ Department of Clinical Nursing \\ Institute of Nursing and Midwifery \\ Faculty of Health Sciences \\ Jagiellonian University Medical College \\ 25 Kopernika St., 30-501 Krakow, Poland \\ e-mail: katarzyna.czyzowicz@uj.edu.pl \\ SUBMITTED: 22.10 .2020 \\ ACCEPTED: 13.11 .2020 \\ DOI: https://doi.org/10.5114/ppiel.2020.103534
}

\begin{abstract}
Introduction: Student surveys confirm the incidence of depressive disorders with multifactorial origin, often with an atypical image, which can cause a lack of specific help. Therefore, an important role of the university is to provide students with conditions that promote mental health and show support in didactic process.

Aim of the study: To assess incidence of depressive disorders among students of a second-cycle programme of the Faculty of Health Sciences, Department of Medical College, Jagiellonian University, Cracow.

Material and methods: The study covered 236 students in the following faculties: obstetrics, nursing, and physiotherapy, aged 21-54 years. A diagnostic questionnaire method, survey technique was used with use of the author's questionnaire, Beck Depression Inventory (BDI-II) and Rosenberg Self-Esteem Scale (SES). Results were developed in Statistica 13.1 program, and the statistical significance level was assumed to be $p<0.05$.

Results: Depressive disorders, usually of mild or moderate severity, were confirmed in every third student. They appeared in individuals who declared other than positive relations with family, suicidal thoughts, depressive disorders in loved ones, feeling stress, and experiencing or witnessing a traumatic event. Positive correlations were confirmed between incidence of depressive disorders and loss of interest and joy, sense of sadness, depression, fatigue, exhaustion and rejection, pessimistic vision of future, anxiety, difficulty in focusing attention, avoiding social contacts, inability to solve problems, aggressiveness, impulsivity and low self-esteem.

Conclusions: Multidimensional relations between the incidence of depressive disorders in students and sociodemographic, psychological, and health-related factors, and the course of studies require an in-depth study, the results of which will allow us to take action to improve support systems aimed at improving the mental condition of students. Key words: depressive disorders, student, support.
\end{abstract}

\section{INTRODUCTION}

Multidimensional relation between undertaking studies and a student's mental condition is a subject of interest for many researchers. This stage in life shapes the first, full independence, at the same time postponing the introduction into "adult life", but it is also a time to experience separation from the family and stress associated with emotional and intellectual effort. For many people, this situation can be a cause of mental crisis [1].

The incidence of depressive disorders is related to the stage of study - at first, adaptation to academic life, experiencing failure, and at a later stage, disappointment with the faculty, dissatisfaction with the organisation and level of teaching, or the subject matter treated by lecturers [1]. The choice of a course of study, career path, struggling with competition, and the pressure of rapid change are also not without significance $[2,3]$. The methods and forms of distance learning may also cause negative psychological effects such as fatigue, overload of tasks to be performed, and burnout, and contribute to the quality of students' lives. Remote working requires students to be independent, self-disciplined and able to work on their own. Lack of these features is associated with the feeling of stress. An additional factor generating stress in the course of remote learning is the lack of one's own room to learn and the possibility of full participation in on-line classes. Students' 
opinions confirm that remote learning contributes to mood swings, worsening of relationships with peers and teachers, and physical and mental exhaustion and fatigue [4].

The factors associated with depressive disorders in students include genetic, cultural and environmental factors, gender, personality traits, and socio-economic status [2, 5]. Other factors predisposing to the development of depressive disorders during this period include the conflict of value systems, difficulties in assuming new social roles, identity crises, as well as a rapid pace of life, consumerism, the pursuit of "happiness at all costs" [2], and low self-esteem [6].

Depressive disorders in young people are often unrecognised due to unusual behaviour, treated as adolescent rebellion [7]. The most common symptoms are difficulty in focusing attention, deteriorating memory, fear of public speaking, negative judgment of appearance, difficulties in making decisions, anxiety about the future and health, a sense of constant fatigue, mental retardation, sadness, and depression as well as irritability and anxiety [8, 9]. The greatest risks of depressive disorders are suicidal thoughts and attempts [10].

The specificity of mental disorders among students shows how important it is for universities to create conditions that promote mental health and support students in the teaching process. Therefore, cooperation with mental health specialists should be taken into account, and the type of support offered by the university should be determined. An important role in this area is played by an individual approach to students and taking into account their health and resources depending on the field of study. In the cooperation between the student and supporting person it is important to trust each other and at the same time use the appropriate specialist treatment $[1,2,9]$.

\section{AIM OF THE STUDY}

To assess the incidence of depressive disorders among students of a second-cycle programme of the Faculty of Health Sciences, Department of Medical College, Jagiellonian University in Cracow.

\section{MATERIAL AND METHODS}

The research covered 236 students of second-degree studies of the Faculty of Health Sciences, Department of Medical College, Jagiellonian University in the following faculties: nursing $-40.7 \%(n=96)$, obstetrics $-27.5 \%(n=65)$, and physiotherapy $-31.8 \%$ $(n=75)$, between October 2019 and January 2020. After obtaining information about the purpose of this study and the way of supplementing the research tools, the students gave their consent to participate in a survey by filling in questionnaires as well as scale and inventory sheets in a paper version. The research took place during didactic classes.

\section{Characteristics of the studied group}

The majority of respondents were women $-92.4 \%$ $(n=218)$. The average age was $23.36 \pm 3.51$ years (age range from 21 to 54 years). In the study group $59.3 \%$ $(n=140)$ of students were in a relationship and $2.5 \%$ $(n=6)$ were parents. Most of the respondents, $90.3 \%$ $(n=213)$, had siblings. For $72.4 \%$ of the respondents, taking up higher education was related to accommodation in a dorm or renting a flat/room. For $64.4 \%$ ( $n=152$ ) of students the time spent at the university usually ranged from 15 to 30 hours per week, and the burden of a large number of classes was felt by $57.6 \%$ $(n=136)$ of the respondents.

The relationship with family was positive for $91.1 \%(n=215)$ of students, and $96.2 \%(n=227)$ of respondents could count on family support. Contact with people with depressive disorders in the immediate vicinity was reported by $23.3 \%(n=55)$ of the respondents, of which $78.2 \%(n=43)$ of the indications concerned the family.

Sense of stress several times a week was confirmed by $40.7 \%$ ( $n=96)$ of students and daily $21.6 \%$ $(n=51)$. The most common way to react in this situation was to look for ways to solve the problem $53.8 \%(n=127)$ or waiting for support from relatives $-25.4 \%(n=60)$. In the surveyed group of students $57.2 \%(n=135)$ admitted that they participated in or witnessed a traumatic event (death of a loved one, threat to another person's life, domestic violence, and bullying). The experience of crisis situations was the reason why $1.7 \%(n=4)$ of respondents attempted suicide, and $20.3 \%(n=48)$ of respondents admitted to the presence of suicidal thoughts at some time.

Students were asked to indicate how often the selected behaviours and emotions accompany them. On the 4-point frequency scale, the highest arithmetic mean was found in case of fatigue, exhaustion $(\bar{x}=2.62 \pm 0.85)$, feeling of sadness, depression $(\bar{x}=2.2 \pm 0.91)$ and difficulty in focusing attention $(\bar{x}=2.17 \pm 0.78)$, and the lowest in the case of anxiety $(\bar{x}=0.95 \pm 0.99)$ and aggressiveness $(\bar{x}=1.02 \pm 0.83)$ (Table 1).

On the Rosenberg Self-Esteem Scale (SES) measuring the self-esteem level, the respondents received an average of $29.45 \pm 5.57$ points.

Statistical analysis showed that $37.7 \%(n=89)$ of respondents had low self-esteem, $25.8 \%(n=61)$ had medium self-esteem, and $36.4 \%(n=86)$ had high self-esteem.

In the conducted research, the author's questionnaire, the SES scale, and Beck's Depression Inventory - second edition (BDI-II) were used. On the basis of 
Table 1. Frequency of accompanied selected behaviours and emotions among the subjects

\begin{tabular}{lcc}
\hline \multirow{2}{*}{$\begin{array}{l}\text { Behaviours and emotions } \\
\text { accompanying the subjects }\end{array}$} & \multicolumn{2}{c}{ Frequency } \\
\hline Feeling tired, exhausted & 2.62 & SD \\
\hline Sense of sadness, depression & 2.20 & 0.85 \\
\hline Difficulties in focusing attention & 2.17 & 0.78 \\
\hline Impulsiveness & 2.04 & 0.93 \\
\hline Reduced self-esteem & 2.02 & 1.11 \\
\hline Pessimistic vision of the future & 1.66 & 1.10 \\
\hline Loss of interest, feeling of joy & 1.60 & 1.02 \\
\hline Avoiding contacts and socialising & 1.44 & 0.85 \\
\hline Sense of rejection & 1.39 & 1.06 \\
\hline Inability to solve problems & 1.35 & 0.89 \\
\hline Aggressiveness & 1.02 & 0.83 \\
\hline Anxiety situations & 0.95 & 0.99 \\
\hline $\bar{x}$-average, SD - standard deviation, 0-never, 1-rarely, 2- sometimes, \\
\hline - frequently, 4-very often & &
\end{tabular}

the questionnaire, the sociodemographic data concerning the course of studies and leisuretime activities, health situation, and self-assessment were collected. The SES scale examines the overall level of self-esteem and consists of 10 statements. Answers are given on a 4-level scale, where 1 means definitely agree and 4 means definitely disagree. Each answer is given 1 to 4 points. The range of points to be scored is from 10 to 40 points - the higher the score, the higher the self-esteem [11]. Beck Depression Inventory - second edition is a self-descriptive tool for measuring the severity of depression. This inventory consists of 21 groups of statements, and results are calculated by adding points from 21 statements. Each item is evaluated using a 4-stage scale. For each group of statements, it is possible to obtain from 0 to 3 points. A maximum of 63 points can be obtained. The following cut-off points are used in the interpretation of results: $0-13$ - lack/minimal depression, 14-19 - mild, 20-28 - moderate, and 29-63 severe [12].
The obtained results were developed in Statistica 13.1 software. The following variables were used for analysis: Mann-Whitney $U$ test and $\chi^{2}$ test. The Spearman's rank correlation coefficient was used to determine the correlation between 2 variables that did not meet the criterion of normal distribution. The statistical significance level was assumed to be $p<0.05$.

\section{RESULTS}

\section{The severity of depressive disorders among students of obstetrics, nursing, and physiotherapy}

In the Beck Depression Inventory, students received an average of $10.09 \pm 8.63$ points. The highest score in BDI-II scale was obtained by physiotherapy students ( $\bar{x}=10.97 \pm 9.22$ points), followed by obstetrics $(\bar{x}=10.05 \pm 8.71$ points $)$ and nursing $(\bar{x}=9.44 \pm 8.12$ points). The results of the BDI-II Inventory among the surveyed students are presented in Table 2.

The number of points in the BDI-II scale, indicating the lack of depression, was $70.3 \%(n=116)$. Mild depression was observed in $14.4 \%(n=34)$, moderate depression in $10.6 \%(n=25)$, and severe depression in $4.7 \%(n=11)$. The severity of depressive disorders among students of particular faculties is presented in Table 3.

\section{Relations between the incidence of depressive disorders and selected variables}

The statistical analysis did not show any relations between the incidence of depressive disorders and gender $(p=0.472)$, marital status $(p=0.878)$, having siblings ( $p=0.295)$, permanent place of residence of the subjects $(p=0.137)$, and place of residence during studies ( $p=0.396)$. Due to the lack of age diversity, the relationship between the severity of depressive disorders and the age of students in younger and older age groups was not analysed. The analysis of relations between the occurrence of depressive disorders and factors related to the course of studies showed that there was no relation between the incidence of

Table 2. Results of Beck Depression Inventory (BDI) among the surveyed students

\begin{tabular}{|c|c|c|c|c|c|c|c|}
\hline Field of study & \multicolumn{7}{|c|}{ Results on BDI-II scale (points) } \\
\hline Obstetrics & 10.05 & 8.71 & 8.00 & 0.00 & 34.00 & 3.00 & 15.00 \\
\hline Nursing & 9.44 & 8.12 & 8.00 & 0.00 & 32.00 & 3.00 & 14.50 \\
\hline Physiotherapy & 10.97 & 9.22 & 10.00 & 0.00 & 37.00 & 3.00 & 17.00 \\
\hline Significance & \multicolumn{7}{|c|}{$\mathrm{H}=0.91, p=0.635$} \\
\hline
\end{tabular}


Table 3. Severity of depressive disorders on the basis of the BDI-II scale among the respondents in particular fields of study

\begin{tabular}{lccc}
\hline \multirow{2}{*}{ Depression } & \multicolumn{3}{c}{ Field of study } \\
\cline { 2 - 4 } & Obstetrics & Nursing & Physiotherapy \\
\cline { 2 - 4 } & $\%(n)$ & $\%(n)$ & $\%(n)$ \\
\hline Lack & $70.8(46)$ & $74.0(71)$ & $65.3(49)$ \\
\hline Mild & $12.3(8)$ & $13.5(13)$ & $17.3(13)$ \\
\hline Moderate & $12.3(8)$ & $7.3(7)$ & $13.3(10)$ \\
\hline Severe & $4.6(3)$ & $5.2(5)$ & $4.0(3)$ \\
\hline \%-percen
\end{tabular}

$\%$-percentage, $n$-number of observations

these disorders and the number of hours spent at the university $(p=0.196)$ and the sense of burden resulting from studying $(p=0.442)$. There was no statistically significant correlation between the incidence or absence of depressive disorders and the field studied $(p=0.470)$, as well as between the level of depressive disorders in the surveyed students and the field studied by them $(p=0.812)$.

A relation was shown between the incidence of depressive disorders among the students and their assessment of family relationships - depressive disorders were more common in people describing their relationships as other than positive $(p=0.004)$. The presence of a statistically significant correlation was also shown between the occurrence of depressive disorders among students and the presence of depressive disorders in their relatives $(p<0.001)$. The subjects who had symptoms of depression more often confirmed the presence of depressive disorders in their loved ones.

A statistically significant correlation $(p<0.001)$ was reported between the incidence of depressive disorders and the frequency of stress - people with depressive disorders more often declared daily stress. Individuals who had symptoms of depressive disorders also more often participated in or witnessed a traumatic event $(p=0.010)$. The results also confirmed the relation $(p<0.001)$ between the incidence of depressive disorders among the subjects and the presence of suicidal thoughts. Individuals with depressive symptoms more often declared the presence of suicidal thoughts.

Analysis of the relationship between the selected behaviours and emotions and the incidence of depressive disorders in the studied group confirmed that people who had symptoms of depressive disorders presented the following behaviours and emotions more frequently (Table 4).

The study confirmed that the incidence of depressive disorders correlated negatively with the results obtained in the SES scale $(p<0.001, R=-0.68)$. The better the self-esteem of subjects, the less frequent were the symptoms of depressive disorders, and vice versa.
Table 4. Relations between the incidence of depressive disorders based on BDI-II scale and the frequency of accompanying selected behaviours and emotions

\begin{tabular}{lcc}
\hline $\begin{array}{l}\text { Depressive disorders/selected } \\
\text { behaviour and emotions }\end{array}$ & $R$ & $p$ \\
\hline Aggressiveness & 0.28 & $<0.001$ \\
\hline Impulsiveness & 0.19 & 0.004 \\
\hline Sense of sadness, depression & 0.61 & $<0.001$ \\
\hline Loss of interest, feeling of joy & 0.63 & $<0.001$ \\
\hline Avoiding contacts and socialising & 0.46 & $<0.001$ \\
\hline Inability to solve problems & 0.40 & $<0.001$ \\
\hline Sense of rejection & 0.51 & $<0.001$ \\
\hline Anxiety situations & 0.53 & $<0.001$ \\
\hline Feeling tired, exhausted & 0.51 & $<0.001$ \\
\hline Difficulties in concentration & 0.47 & $<0.001$ \\
\hline Pessimistic vision of the future & 0.55 & $<0.001$ \\
\hline$R$ - value of Spearman's rank correlation, $p-$ value of test probability
\end{tabular}

\section{DISCUSSION}

Analysis of the epidemiological situation concerning the incidence of depressive disorders proves that there are more and more students struggling with such problems. The risk of depressive disorders is associated, among others, with a new mode of education, building interpersonal relations, adaptation to the new environment, as well as the assumption of independence and responsibility $[9,13]$. Hamasha et al. [14] showed that the presence of mental illness, lifestyle, the recent loss of a family member, and dissatisfaction with the teaching staff are risk factors for depressive disorders among students. However, Yousef et al. [15] showed that one of the main factors associated with depression in a group of surveyed nursing students was family pressure to choose the profession of nurse and lack of other opportunities for professional development. The conducted research shows that these circumstances are more important risk factors of depression in first-year students than in older students [16].

In our own research, the results obtained on the basis of the BDI-II scale (10.09 \pm 8.63 points) indicate the lack/minimum occurrence of depressive symptoms among students. In the vast majority of respondents, no depressive disorders were found, but nearly $1 / 3$ of them had depressive symptoms of varying severity. Jaworska et al. [13] obtained similar results (9.26 \pm 6.32 points) among students of the Academy of Physical Education. For comparison, in the study conducted by Adamiak et al. [17], the incidence of depressive disorders was observed in every third person in the second year and in 14\% of fourth-year students of the Faculty of Medicine. The analysis of literature by Suwalska et al. [18] confirms that up to $30 \%$ of medical students may suffer from depression. 
The statistical analysis did not show any correlation between the incidence of depressive disorders among the surveyed students and the field of study. Different results were presented by Pietras et al. [19] - the risk of these disorders was 5 times higher in the group of students of pedagogy than in students of economics. The results of Zagdańska and Kiejna [1] confirm that the prevalence of depressive disorders among students of the humanities and pedagogical faculties was higher in comparison with students of medical, technical, architectural, and IT faculties. In turn, studies by Bresolin et al. [20] showed that speech therapy and nursing were the faculties where symptoms of moderate to severe depression were the most frequent in comparison with other medical faculties. The study also did not show any correlation between the incidence of depressive disorders and the number of hours spent at the university or a sense of burden on studies. However, studies conducted by Mikolajczyk et al. [21] and Alvi et al. [22] showed that the symptoms of these depressive disorders were more frequent in students who declared a sense of burden.

The obtained results did not confirm a relationship between the incidence of depressive disorders and gender, but the small number of men participating in this study should be emphasised. Statistical analysis also did not confirm the relationship between the incidence of these disorders and the marital status of students and their place of residence during their studies. The significant relations between the incidence of depressive disorders and gender and place of residence during studies were also not obtained by Mojs and Strzelecki [2]. Similar results with respect to gender, marital status, and place of residence during the study period were shown by Oskouei and Kahkeshan [23], and with respect to gender and marital status by Talaei et al. [24]. The studies of Tiji et al. [25] also did not confirm the relations between depression among students with gender, and the studies of Alvi et al. [22] with their place of residence in relation to their studies. However, the results of studies conducted by Jaworska et al. [13], Pietras et al. [19], Santangelo [26], and Mikolajczyk et al. [21] confirmed the relations between the incidence of depressive disorders and gender, showing that female gender increases the risk of depression. Similarly, the prevalence of depressive disorders was higher in the Cam and Top studies [27], while studies conducted by Mohebbi et al. [28] showed that it was students who had a higher rate of depression. In turn, studies by Zagdańska and Kiejna [1] and Mikolajczyk et al. [21] found that students who were not in relationships were significantly more likely to experience depressive episodes.

The type of relationship with family $[29,30]$ is important in the genesis of depressive disorders, and this was also found in our own research (more frequent occurrence of disorders in non-positive re- lationships). At the same time, no relations between the incidence of depressive disorders and having siblings have been shown. Similarly, in the studies by Alvi et al. [22] there was no correlation between the number of siblings and the occurrence of disorders. However, Sherina and Nadarajan [31] indicated that those who had bad relationships with siblings were significantly more likely to show symptoms of depressive disorders.

In our study, the incidence of depressive disorders was more frequent among students who declared the presence of depressive disorders in their relatives. Similar results were obtained by Kumar et al. [32] and Hirata et al. [33]. Different results were presented by Alvi et al. [22] and Tija et al. [25].

One of the symptoms of depressive disorders is suicidal thoughts [34]. In the surveyed students, the relations between the incidence of depressive disorders and the presence of suicidal thoughts were proven the incidence of disorders correlated positively with the presence of suicidal thoughts. The same results were obtained in Arria et al. [35] and Beck et al. [12].

Circumstances related to studying and the need to make various decisions can be a burden for students and cause a feeling of stress. The more often students were exposed to stress, the more depressive symptoms were observed. Studies conducted by Nowak et al. [36] showed a similar relation.

One of the strongest stressors associated with depressive disorders in young people is trauma [29]. Our own research has shown a statistically significant relation between the experience of trauma and the incidence of depressive disorders. The same results were obtained by Vrana and Lauterbach [37].

Our research also showed strong positive correlations between the incidence of depressive disorders and the frequency of selected behaviours and emotions, such as aggressiveness, impulsiveness, feelings of sadness and depression, loss of interest and joy, avoidance of contacts and social encounters, inability to solve problems, sense of rejection, anxiety, fatigue and exhaustion, difficulty in focusing attention, and a pessimistic vision of the future. Similarly, studies conducted by Beck et al. [12] showed positive correlations between the incidence of depressive disorders and aversion, difficulty in concentration, indecisiveness, loss of energy, hobbies, pleasure and exhaustion, sadness, pessimism, anxiety, and suicidal thoughts.

Self-esteem plays an important role in the aetiology of depressive disorders, and it has been shown that people with low self-esteem are more likely to experience it $[6,38]$. In our own research, depressive disorders were more common in students with low selfesteem. A similar correlation was shown by Michalak et al. [39]. Armstrong and Oomen-Early [40] also found a significant negative correlation between the occurrence of disorder and the level of self-esteem. 
Furegato [41], on the other hand, showed that depression in nursing students was associated with an average level of self-esteem.

The appearance of depressive symptoms of varying severity does not always trigger a desire to seek help. However, some authors point out that already mild depressive symptoms are a serious problem of mental health, and students should be motivated to seek professional help [42]. According to some researchers, it is possible to identify threats to mental health among students. Identification of these threats, with the use of screening tools, will allow us to undertake interventions shaping the students' ability to monitor their own health condition and to seek professional help. This is extremely important in the case of nursing students because their good mental state is important for the whole area of health care [43].

\section{CONCLUSIONS}

The existence of depressive disorders among students is common with multidimensional relations.

Research results can be used in the practice of educating medical students.

The analysis of risk factors related to depressive disorders in students requires an in-depth study.

Results of in-depth studies of multidimensional relations between the incidence of depressive disorders among students and sociodemographic, psychological, and health-related factors and the course of studies will allow us to take action to improve support systems aimed at improving the mental condition of students.

\section{Disclosure}

The authors declare no conflict of interest.

\section{References}

1. Zagdańska M, Kiejna A. Rozpowszechnienie i czynniki ryzyka epizodów depresji wśród wrocławskiej młodzieży akademickiej - wyniki badania epidemiologicznego. Psychiatr Pol 2016; 50: 631-641.

2. Mojs E, Strzelecki W. Wybrane zaburzenia emocji u młodzieży i młodych dorosłych na przykładzie depresji. Polityka Spol 2013; 2: 22-27.

3. Strzelecki D. Stabilizatory nastroju w leczeniu choroby afektywnej dwubiegunowej. Psychoterapia i Uzależnienia 2017; 2: 1-7.

4. Długosz P. Raport z II etapu badań studentów UP. Opinia na temat zdalnego nauczania i samopoczucia psychicznego. Instytut Filozofii i Socjologii Uniwersytetu Pedagogicznego im. Komisji Edukacji Narodowej w Krakowie, Kraków 2020.

5. Eisenberg D, llunt J, Speer N. Mental health in American colleges and uniwersities: variation across student subgroups and across campuses. J Nerv Ment Dis 2013; 201: 60-67.

6. Ogińska-Bulik N. Psychologiczne zasoby sprzyjające zdrowiu. In: Edukacja zdrowotna. Woynarowska B (Ed.). Wydawnictwo Naukowe PWN, Warszawa 2017; 46-57.
7. Mojs E, Bartkowska W, Kaczmarek ŁD, et al. Właściwości psychometryczne polskiej wersji skróconej Skali Depresji Kutchera dla Młodzieży (Kutcher Adolescent Depression Scale) - pomiar depresji w grupie studentów. Psychiatr Pol 2015; 49: 135-144.

8. Szczepańska J, Klin Z, Jaroszewska A, et al. Zaburzenia nastroju w populacji studentów Wydziału Fizjoterapii AWF we Wrocławiu. Część 1. Fizjoterapia 2008; 16: 69-78.

9. Nowak-Adamczyk D. Studenci z zaburzeniami psychicznymi w przestrzeni akademickiej - system wsparcia edukacyjnego na Uniwersytecie Jagiellońskim w Krakowie. Niepełnosprawność - zagadnienia, problemy, rozwiązania 2014; 4: 73-94.

10. Miranda-Mendizabal A, Castellvi P, Alayo I, et al. Gender commonalities and differences in risk and protective factors of suicidal thoughts and behaviors: A cross - sectional study of Spanish university students. Depress Anxiety 2019; 36: 1102-1114.

11. Dzwonkowska I, Lachowicz-Tabaczek K, Łaguna M. Samoocena i jej pomiar. Pracownia Testów Psychologicznych Polskiego Towarzystwa Psychologicznego, Warszawa 2008.

12. Beck AT, Steer RA, Brown GK. BDI - II Inwentarz Depresji Becka. Podręcznik. 2nd ed. Pracownia Testów Psychologicznych Polskiego Towarzystwa Psychologicznego, Warszawa 2019.

13. Jaworska L, Morawska N, Morga P, et al. Analiza częstości występowania objawów depresyjnych wśród studentów Wydziału Fizjoterapii Akademii Wychowania Fizycznego we Wrocławiu w kontekście planów zawodowych. Fizjoterapia 2014; 22: 10-22.

14. Hamasha AA, Kareem YM, Alghamdi MS, et al. Risk indicators of depression among medical, dental, nursing, pharmacology, and other medical science students in Saudi Arabia. Int Rev Psychiatry 2019; 31: 646-652.

15. Yousef S, Athamneh M, Masuadi E, et al. Association between depression and factors affecting career choice among Jordanian nursing students. Front Public Health 2017; 5: 311.

16. Hambisa MT, Derese A, Abdeta T. Depressive symptoms among Haramaya University students in Ethiopia: a crosssectional study. Depress Res Treat 2020; 5027918.

17. Adamiak G, Jabłkowska K, Nowakowska K, et al. System wartości a objawy depresyjne u studentów medycyny. Psychiatria i Psychologia Kliniczna 2009; 9: 178-188.

18. Suwalska J, Suwalska A, Szczygieł M, et al. Studenci medycyna a stygmatyzacja z powodu depresji . Część II. Autostygmatyzacja. Psychiatr Pol 2017; 51: 503-513.

19. Pietras T, Witusik A, Panek M, et al. Nasilenie depresyjności u studentów kierunku pedagogika. Pol Merkur Lekarski 2012; 32: 163-166.

20. Bresolin JZ, Dalmolin GL, Vasconcellos SJL, et al. Depressive symptoms among healthcare undergraduate students. Rev Lat Am Enfermagem 2020; 28: e3239.

21. Mikolajczyk RT, Maxwell AE, Naydenova V, et al. Depressive symptoms and perceived burdens related to being a student: Survey in three European countries. Clin Pract Epidemiol Ment Health 2008; 4: 19.

22. Alvi T, Assad F, Ramzan M, et al. Depression, anxiety and their associated factors among medical students. J Coll Physicians Surg Pak 2010; 20: 122-126.

23. Oskouei NN, Kahkeshan P. A study on depression among paramedical students and the contributing factors in 20102011. J Paramed Sci 2013; 4: 99-105.

24. Talaei A, Ardani AR, Saghebi A. A survey of depression among Iranian medical students and its correlation with social support and satisfaction. J Pak Psychiatr Soc 2008; 5: 90-99. 
25. Tjia J, Givens JL, Shea JA. Factors associated with undertreatment of medical student depression. J Am Coll Health 2005; 53: 219-224.

26. Santangelo OE, Provenzano S, Giordano D. Nursing students and depressive symptomatology: an observational study in University of Palermo. Ment IIIn 2019; 11: 25-31.

27. Cam HH, Top FU. The relationship between health-related quality of life and prevalence of depressive symptoms among undergraduate nursing students in Turkey. Med Sci 2018; 7: 154-157.

28. Mohebbi Z, Setoodeh G, Torabizadeh C, et al. State of mental health and associated factors in nursing students from southeastern Iran. Invest Educ Enferm 2019; 37: e04.

29. Gałecki P, Szulc A. Psychiatria. Edra Urban \& Partner, Wrocław 2018.

30. Harper JM, Padilla-Walker LM, Jensen A. Do siblings matter independent of both parents and friends? Sympathy as a mediator between siblings relationship quality and adolescent outcomes. J Res Adolesc 2014; 26: 101-114.

31. Sherina MS, Nadarajan K. The prevalence of depression among medical students. Malaysian Journal of Psychiatry 2003; 11: 12-17.

32. Kumar GS, Jain A, Hegde S. Prevalence of depression and its associated factors using Beck Depression Inventory among students of a medical college in Karnataka. Indian J Psychiatry 2012; 54: 223-226.

33. Hirata FC, Lima MC, de Bruin VM, et al. Depression in medical school: the influence of morningness-eveningness. Chronobiol Int 2007; 24: 939-946.

34. Makara-Studzińska M. Pacjent z ryzykiem samobójczym. In: Komunikacja w opiece medycznej. Makara-Studzińska M (Ed.). Medical Education, Warszawa 2017; 195-204.

35. Arria AM, O'Grady KE, Caldeira KM, et al. Suicide ideation among college students: A multivariate analysis. Arch Suicide Res 2009; 13: 230-246.

36. Nowak G, Żelazko A, Nowak D, et al. Zależność między zachowaniami zdrowotnymi a poziomem stresu i występowaniem bezsenności oraz depresji u studentów zdrowia publicznego. Pielęgniarstwo i Zdrowie Publiczne 2015; 5: 231-238.

37. Vrana S, Lauterbach D. Prevalence of traumatic events and post-traumatic psychological symptoms in a nonclinical sample of college students. J Trauma Stress 1994; 7: 289-302.

38. Wilczewska A. Samoocena i poziom depresji studentów kierunków pedagogicznych i niepedagogicznych. Rozprawy Społeczne 2013; 1: 109-116.

39. Michalak J, Teismann T, Heidenreich T, et al. Buffering low self-esteem: The effect of mindful acceptance on the relationship between self-esteem and depression. Pers Individ Dif 2011; 50: 751-754.

40. Armstrong S, Oomen-Early J. Social connectedness, selfesteem and depression symptomatology amoung collegiate athletes versus nonathletes. J Am Coll Health 2009; 57: 521-526.

41. Furegato AR, Santos JL, da Silva EC. Depression among nursing students associated to their self-esteem, health perception and interest in mental health. Rev Lat Am Enfermagem 2008; 16; 198-204.

42. Milić J, Škrlec I, Milić I, et al. High levels of depression and anxiety among Croatian medical and nursing students and the correlation between subjective happiness and personality traits. Int Rev Psychiatry 2019; 31: 653-660.

43. Hsiung DY, Tsai CL, Chiang LC, et al. Screening nursing students to identify those at high risk of poor mental health: a cross-sectional survey. BMJ Open 2019; 9: e025912. 